\title{
Investigation of body and udder skin surface temperature differentials as an early indicator of mastitis in Holstein Friesian crossbred cows using digital infrared thermography technique
}

M. Sathiyabarathi ${ }^{1}$, S. Jeyakumar ${ }^{1}$, A. Manimaran ${ }^{1}$, Heartwin A. Pushpadass $^{2}$, M. Sivaram ${ }^{3}$, K. P. Ramesha ${ }^{4}$, D. N. Das ${ }^{4}$, Mukund A. Kataktalware ${ }^{4}$, G. Jayaprakash ${ }^{5}$ and Tapas Kumar Patbandha ${ }^{6}$

1. Livestock Research Centre, Southern Regional Station, Indian Council of Agricultural Research - National Dairy Research Institute, Adugodi, Bengaluru - 560 030, Karnataka, India; 2. Dairy Engineering Section, Southern Regional Station, Indian Council of Agricultural Research - National Dairy Research Institute, Adugodi, Bengaluru - 560030 , Karnataka, India; 3. Dairy Economics and Statistics, Southern Regional Station, Indian Council of Agricultural

Research - National Dairy Research Institute, Adugodi, Bengaluru - 560 030, Karnataka, India; 4. Dairy Production Section, Southern Regional Station, Indian Council of Agricultural Research - National Dairy Research Institute, Adugodi, Bengaluru - 560 030, Karnataka, India; 5. Department of Animal Nutrition, College of Veterinary and Animal Sciences, Mannuthy - 680 651, Kerala, India; 6. Livestock Production and Management Section, Indian Council of Agricultural

Research - National Dairy Research Institute, Karnal - 132 001, Haryana, India.

Corresponding author: S. Jeyakumar, e-mail: jeyakumarsakthivel@gmail.com,

MS: drmsathiyabarathi@gmail.com, AM: maranpharma@gmail.com, HAP: heartwin1@gmail.com,

MS: sivaram.ndri@gmail.com,KPR: kpragb@gmail.com,DND: dndasndri@gmail.com, MAK: mtalware@gmail.com, G]: drgjayaprakash@gmail.com, TKP: patbandhavet@gmail.com

Received: 11-08-2016, Accepted: 08-11-2016, Published online: 08-12-2016

doi: 10.14202/vetworld.2016.1386-1391 How to cite this article: Sathiyabarathi M, Jeyakumar S, Manimaran A, Pushpadass HA, Sivaram M, Ramesha KP, Das DN, Kataktalware MA, Jayaprakash G, Patbandha TK (2016) Investigation of body and udder skin surface temperature differentials as an early indicator of mastitis in Holstein Friesian crossbred cows using digital infrared thermography technique, Veterinary World, 9(12): 1386-1391.

\section{Abstract}

Aim: The objective of this study was to investigate the ability of infrared thermography (IRT) technique and its interrelationship with conventional mastitis indicators for the early detection of mastitis in Holstein Friesian (HF) crossbred cows.

Materials and Methods: A total of 76 quarters of lactating HF crossbred (Bos indicus $\times$ Bos taurus) cows (n=19) were monitored for body temperature (i.e., eye temperature) and udder skin surface temperature (USST) before milking using forward-looking infrared (FLIR) i5 camera. Milk samples were collected from each quarter and screened for mastitis using Somatic Cell Count (SCC), Electrical Conductivity (EC), and California mastitis test. Thermographic images were analyzed using FLIR Quick Report 1.2 image analysis software. Data on body and USST were compiled and analyzed statistically using SPSS 16.0 and Sigmaplot 11.

Results: The mean \pm standard deviation (SD) body $\left(37.23 \pm 0.08^{\circ} \mathrm{C}\right)$ and USST $\left(37.22 \pm 0.04^{\circ} \mathrm{C}\right)$ of non-mastitic cow did not differ significantly; however, the mean USST of the mastitis-affected quarters were significantly higher than the body temperature and USST of unaffected quarters $(\mathrm{p}<0.001)$. The mean \pm SD USST of the subclinical mastitis $(\mathrm{SCM})$ and clinical mastitis-affected quarters were $38.08 \pm 0.17{ }^{\circ} \mathrm{C}$ and $38.25 \pm 0.33{ }^{\circ} \mathrm{C}$, respectively, which is 0.72 and $1.05^{\circ} \mathrm{C}$ higher than the USST temperature of unaffected quarters. The USST was positively correlated with EC $(r=0.95)$ and SCC $(r=0.93)$. The receiver operating characteristic curve analysis revealed a higher sensitivity for USST in early prediction of SCM with a cut-off value of $>37.61{ }^{\circ} \mathrm{C}$.

Conclusion: It is concluded that infrared thermal imaging technique could be used as a potential noninvasive, quick cowside diagnostic technique for screening and early detection of SCM and clinical mastitis in crossbred cows.

Keywords: diagnosis, lactating cows, mastitis, temperature.

\section{Introduction}

India ranks first in milk production, accounting for $18.5 \%$ of world milk production, achieving an annual output of 146.3 million tons during 2014-15 as compared to 137.69 million tons during 2013-14 recording a growth of $6.26 \%$. Whereas, the Food and

Copyright: Sathiyabarathi, et al. Open Access. This article is distributed under the terms of the Creative Commons Attribution 4.0 International License (http://creativecommons.org/licenses/ by/4.0/), which permits unrestricted use, distribution, and reproduction in any medium, provided you give appropriate credit to the original author(s) and the source, provide a link to the Creative Commons license, and indicate if changes were made. The Creative Commons Public Domain Dedication waiver (http:// creativecommons.org/publicdomain/zero/1.0/) applies to the data made available in this article, unless otherwise stated.
Agriculture Organization [1] has reported that 3.1\% increase in world milk production from 765 million tons in 2013 to 789 million tons in 2014. However, with the increase in milk production, there is increase in the incidence of production diseases especially mastitis [2].

The dairy industry is facing a great setback due to the high prevalence and incidence of mastitis in dairy cattle [3]. The prevalence of subclinical mastitis ( $\mathrm{SCM}$ ) and clinical mastitis among non-descript, Deoni, Jersey and Holstein Friesian (HF) cows were $40.8 \%, 36.1 \%, 47.8 \%$, and $54.7 \%$ and $3.8 \%, 1.8 \%$, $10.1 \%$ and $13.2 \%$, respectively [4]. The incidence of mastitis in Karan Fries, Karan Swiss, Sahiwal, and 
Tharparkar cows was reported to be $36.90 \%, 38.46 \%$, $33.98 \%$ and $33.44 \%$, respectively. The incidence was highest in fourth parity and above and lowest in first parities [5]. The global estimated economic loss per year due to mastitis amounts to USD 35 billion and $₹ 6000$ crores for Indian dairy industry in which SCM is responsible for approximately $70-80 \%$ (₹4365 crore) of economic losses [6]. Milk production losses due to SCM amounted to $272 \mathrm{~kg}$ per lactation of nontreated cows in Lithuanian University Farm [7].

Early detection of mastitis is most important to prevent the losses associated with decreased milk production, quality and make decisions for quick and effective treatment. Skin temperature reflects the state of tissue metabolism and blood circulation; abnormal thermal patterns can signify areas of superficial inflammation or circulatory impairments. Infrared thermography (IRT) is employed as a diagnostic tool and shown to be sensitive enough to detect changes in udder skin surface temperature (USST) of healthy and mastitis-affected quarters [8-11]. A perusal of literature revealed that there are no reports available to establish whether a natural infection with a common course of events and its associated changes with mastitis are possible for detection by IRT in an organized dairy herd. This study was undertaken to assess the body and USST differentials using IRT for early detection of naturally occurring SCM and clinical mastitis in HF crossbred cows reared under subtropical conditions.

\section{Materials and Methods}

\section{Ethical approval}

Thermal imaging and milk sampling were performed as per the guidelines of the National Dairy Research Institute (NDRI) Animal Ethical Committee for care and use of experimental animals.

\section{Study area and experimental cows}

The study was conducted at Livestock Research Centre (LRC), Southern Regional Station (SRS) of Indian Council of Agricultural Research - NDRI located at an altitude of $1200 \mathrm{~m}$ above sea level on $12^{\circ} 58^{\prime} 53^{\prime \prime} \mathrm{N}$ latitude and $77^{\circ} 36^{\prime} 42^{\prime \prime} \mathrm{E}$ longitudes. The climatic condition of the farm is of subtropical where temperature raises up to $36{ }^{\circ} \mathrm{C}$ in summer and comes closer to $15^{\circ} \mathrm{C}$ during the winter season. The average rainfall ranges from 800 to $1200 \mathrm{~mm}$ and the maximum is received during July to October.

In this study, a total of 76 quarters of apparently healthy lactating HF crossbred (Bos indicus $\times$ Bos taurus) cows $(\mathrm{n}=19)$ from first to sixth parity with an average body weight of $451 \pm 19 \mathrm{~kg}$ and milk yield of $14.4 \pm 0.2 \mathrm{~kg}$ per cow were used. In this study, mastitis was not induced experimentally in any cows, and IRT imaging was done daily in all the cows to detect naturally occurring mastitis due to infection/environmental factors. The animals were maintained under loose housing system and milked twice daily with machine milking system. The cows were provided with recommended concentrate feed, fodder (green and dry) and had free access to water.

\section{Thermal imaging and milk sampling}

A total number of 1064 eyes and 4256 skin surface thermal images of udder quarter were taken before morning and evening milking using forward-looking infrared (FLIR) i5 camera (FLIR Systems, Inc. 27700 SW Parkway Ave. Wilsonville, OR 97070, USA) continuously for 28 days. Before capturing the image, the camera was calibrated to ambient temperature, and the temperature measurement was adjusted to degree Celsius and distance to meters. The value of emissivity and reflected apparent temperature was kept constant for all the images as 0.98 and $20.0^{\circ} \mathrm{C}$, respectively. A lateral thermographic image of the eye was taken at a distance of $1.0 \mathrm{~m}$ from the lateral side of animal's head to observe cow's body temperature. Thermographic images of udder were taken before milking at a distance of $1.0 \mathrm{~m}$ from the udder. Thermographic images were captured from the lateral side for forequarters and posterior or lateral side for hind quarters of the udder. The thermographic images were analyzed by FLIR Quick Report 1.2 software. The temperature of the inner canthus and the maximum temperature of the udder surface in a particular image was recorded and used in the analysis.

After capturing thermal images of all the quarters, milk samples from each quarter were collected separately during morning milking in a clean polystyrene tube and tested immediately to Somatic Cell Count (SCC) (The PortaSCC ${ }^{\circledR}$ Somatic Cell Test, Whittendale Drive, Suite E Moorestown, NJ 08057 USA), Electrical Conductivity (EC) (Draminski Electronic Mastitis Detector, DRAMINSKI Ul. Owocowa 17 10-860 Olsztyn Poland) and California Mastitis Test (CMT) (Immucell Corporation, 56 Evergreen Drive, Portland) using standard protocol. The quarter which showed SCC of more than 4 lakhs cells per ml of milk in a crossbred cow was considered as mastitis-affected animals [12]. Besides, the animals with CMT score of trace and more than one and cows with more than 50-unit difference of EC values in between four quarters were also considered as mastitis-affected animals.

\section{Statistical analysis}

An analysis of variance was employed to compare the non-mastitis, SCM and clinical mastitis-affected cows with respect to body temperature, USST, EC, and SCC. The correlation between the USST and mastitis indicators of non-mastitis and mastitis-affected cows were performed using a Pearson's test. Correlation $<0.3$ were considered weak, between 0.3 and 0.7 were moderate and above 0.7 were strong. The regression model was employed relating USST with mastitis indicators of non-mastitis and mastitis-affected cows. Receiver operating characteristic (ROC) curve was plotted to compare the sensitivity and specificity of IRT with another test to detect SCM. All the above 
statistical analysis was made using SPSS 16.0 (IBM Corporation, Armonk, New York, USA) and Sigma plot 11 (SYSTAT, Salano, California, USA).

\section{Results and Discussion}

Mastitis is the most common and important economic disease of the dairy industry and has a significant effect on quality of milk [13] and udder health. Early detection of mastitis is important for effective and successful treatment of intramammary infection. There are several techniques and biomarkers are available for early detection of changes in milk associated with SCM and clinical mastitis. However, these diagnostic methods are laboratory oriented, lack full accuracy and needs a considerable time of farm staff or milker $[8,9,11]$. Therefore, a cost-effective, rapid, non-invasive cow-side diagnostic technique with potential application in the field is essential for monitoring udder health.

Automated methods for early and reliable detection of mastitis are currently in focus under precision dairying. In this study, IRT was found as a rapid and non-invasive cow-side technique for early detection of SCM in crossbred cows. Several studies demonstrated the use of IRT for early detection of SCM and clinical mastitis in dairy cows and ewes $[8,11,14]$. Skin temperature reflects the status of tissue metabolism, blood circulation, and abnormal thermal patterns can signify areas of superficial inflammation or circulatory impairments. Clinically, inflammation is characterized by five cardinal signs namely rubor (redness), calor (increased heat), tumor (swelling), dolar (pain), and functio laesa (loss of function). The inflammatory response in mastitis is initially associated with the rise in the temperature of the udder. IRT detects surface heat emitted as infrared radiation. A thermal camera absorbs infrared radiation and generates pictorial images based on the amount of heat generated, without causing radiation exposure [15]. In general, on a thermograph, the warmest areas appear white or red whereas the coolest regions appear blue or black (Figure-1) [10].

In this study, the USST (mean \pm standard deviation $[\mathrm{SD}] /$ range $)$ of the SCM $\left(38.08 \pm 0.17^{\circ} \mathrm{C} /\right.$ $37.90-38.4^{\circ} \mathrm{C}$ ) and clinical mastitis-affected quarter $\left(38.25 \pm 0.33^{\circ} \mathrm{C} / 37.90-38.90^{\circ} \mathrm{C}\right)$ of $\mathrm{HF}$ crossbred cows was higher than temperature of body $\left(37.23 \pm 0.08^{\circ} \mathrm{C} / 37.15-37.31^{\circ} \mathrm{C}\right)$ and non-mastitis quarter $\left(37.22 \pm 0.05^{\circ} \mathrm{C} / 37.14-38.4^{\circ} \mathrm{C}\right)$ by $0.86-1.02^{\circ} \mathrm{C}$ (Figure-2). Hovinen et al. [9] who observed an increase of $1-1.5^{\circ} \mathrm{C}$ in USST associated with lipopolysaccharide (LPS) induced clinical mastitis using IRT in Ayrshire and HF cows. Hurnik et al. [16] suggested that monitoring udder health for detection of mastitis revealed that USST started increasing 3 days before clinical changes and they could detect four out of six cases earlier using IRT and detection ability increased in severe cases. Temperature increases of $+2.3^{\circ} \mathrm{C}$ of USST were detectable through IRT in experimentally

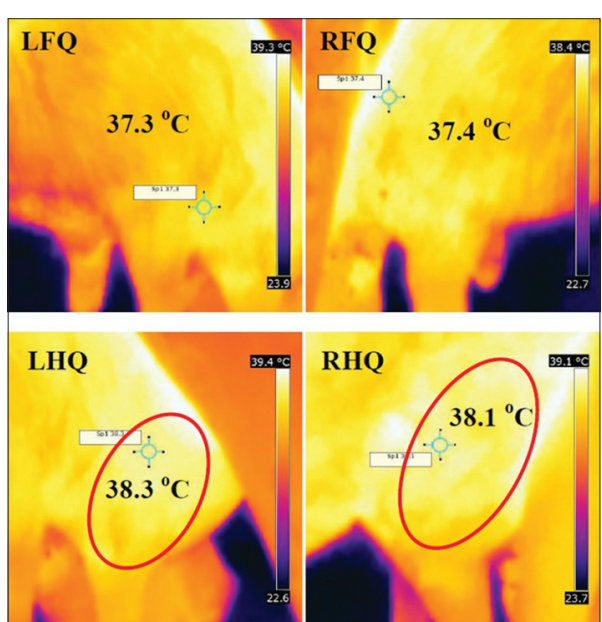

Figure-1: Infrared thermography thermogram of subclinical mastitis-affected Holstein Friesian crossbred cow from the lateral side of udder quarters. LFQ: Left fore quarter, RFQ: Right fore quarter, LHQ: Left hind quarter, RHQ: Right hind quarter. LHQ and RHQ showing increased temperature.

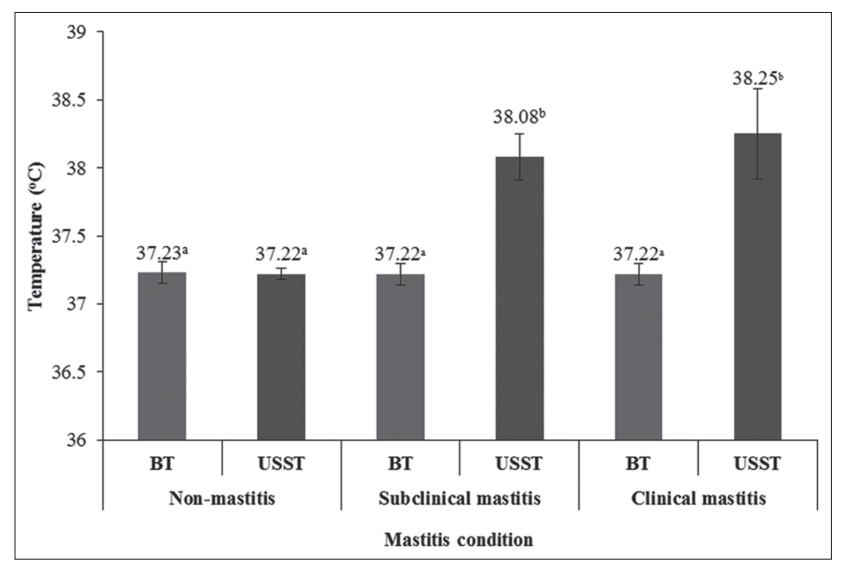

Figure-2: Temperature difference between body and udder skin surface of non-mastitis and mastitis affected crossbred cows. BT: Body temperature, USST: Udder skin surface temperature.

induced mastitis by infusion of bacterial endotoxin [17]. Similarly, Hovinen et al. [9] demonstrated that IRT was capable of detecting $1-1.5^{\circ} \mathrm{C}$ change in temperature difference in udder skin surface associated with clinical mastitis induced by Escherichia coli endotoxin. The thermal camera detects increased USST both in experimentally induced $[9,17]$ and in natural course of infection as demonstrated in this study where the increased USST could be the result of vascular dilatation, loss of capillary permeability and hyperthermia at the site of infection [18].

In this study, affected quarters showed a higher temperature than the unaffected quarters and the temperature differential was $1.0^{\circ} \mathrm{C}$. Willits [19] observed that mastitis causes USST to rise often before other clinical signs are visible. Scott et al. [17] detected a clear rise in temperature of the experimentally induced quarters than the control quarters. Similarly, Hovinen et al. [9] observed a transient rise in rectal temperature of experimentally induced clinical mastitis with 
the simultaneous rise of USST, which was successful, detected using the thermal camera. However, using IRT they could not detect local inflammatory changes of the udder, appearing earlier than the rectal temperature increase. Metzner et al. [11] demonstrated a good correlation between USST and rectal temperature in relation to mastitis-affected hind quarters.

Interestingly, Barth [20] observed that the mean surface temperature of teats increased from $30.1^{\circ} \mathrm{C}$ at the tip to $35.1^{\circ} \mathrm{C}$ at the udder base and USST was higher for mastitis-affected quarters $\left(34.1^{\circ} \mathrm{C}\right)$ with $\mathrm{SCC}$ of $>100,000$ than unaffected (or) healthy quarter $\left(33.6^{\circ} \mathrm{C}\right)$ with $\mathrm{SCC}$ of $<100,000$, and the temperature differential between affected and healthy quarter was $0.5^{\circ} \mathrm{C}$.

Certain cells especially leukocytes presence and its quantity level in the milk are directly related to the severity of infection and type of causative pathogen [21]. SCM is characterized by apparently normal milk but with an increase in SCC of up to 400,000 cells per $\mathrm{ml}$ [22] which further reflects the severity of the infection. Diagnosis of SCM can be made through many methods including direct measurement of SCC or indirectly by performing CMT on suspected quarters. In most of the time, CMT is employed as an appropriate cow-side test for evaluation of udder health reflects the SCC level quite accurately and is a reliable indicator of the severity of infection [23].

Detection of clinical mastitis is mainly based on abnormal milk with SCC of $>500,000$ per $\mathrm{ml}$ and inflammatory changes viz. swelling, pain and consistency, which also depends on the severity of infection and causative organism [24]. Besides, increased SCC and CMT, the score was associated with isolation of causative organism on the microbiological culture of milk sample $[25,26]$. Alterations in EC are of critical importance to assess the quality of milk. The EC of normal milk from healthy quarters varies between 4 and $5.5 \mathrm{mS} / \mathrm{cm}$ at $25^{\circ} \mathrm{C}$ [27] and differential values of EC between four quarters are compared to find out abnormal values related to mastitis-affected quarters. During mastitis, the milk has a higher EC value than normal milk of unaffected quarter, which is due to udder tissue damage and subsequent increase in sodium $\left(\mathrm{Na}^{+}\right)$and chloride $\left(\mathrm{Cl}^{-}\right)$ions in milk [23]. Therefore, changes in EC of milk, when measured in tandem with SCC or CMT score and USST, would serve as a valid diagnostic methodology for detecting early onset of mastitis. Hovinen et al. (2008) observed that LPS challenged mastitis quarter showed increased USST 4-h post challenge than control quarters by $0.6^{\circ} \mathrm{C}$, and this temperature rise was significantly $(\mathrm{p}<0.001)$, parallel with an increase in SCC and EC value of milk from challenged quarters.

Polat et al. [8] studied the interrelationships between USST and other mastitis indicators, viz., SCC and CMT score. The USST was positively correlated with SCC and the CMT score $(r=0.86$; $\mathrm{p}<0.0001$ ), SCM quarter with SCC $>400,000$ cells per $\mathrm{ml}$ showed UST $2.35^{\circ} \mathrm{C}$ more than the healthy quarter

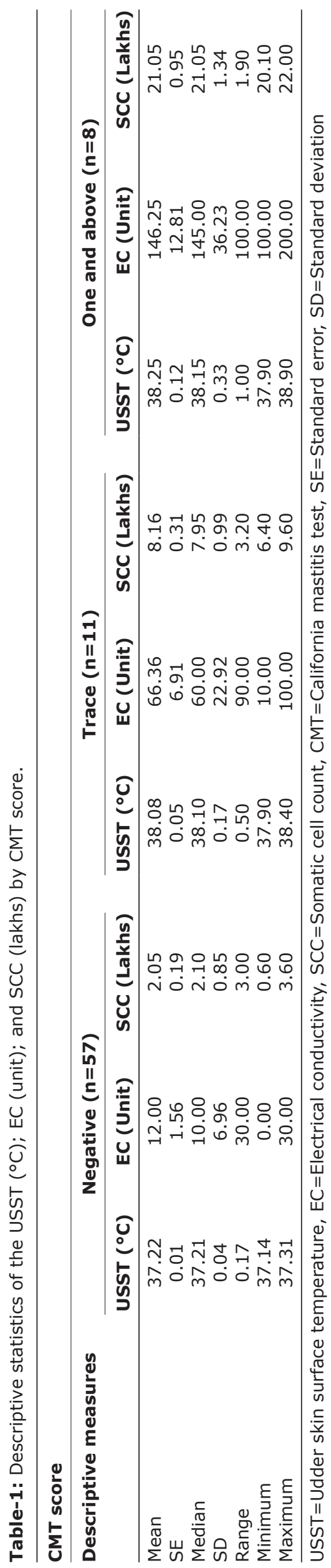

Veterinary World, EISSN: 2231-0916 
Table-2: Comparison of body temperature, USST, EC and SCC (mean \pm SD) of non-mastitis and mastitis-affected HF crossbred cows.

\begin{tabular}{lcccc}
\hline Condition & BT $\left({ }^{\circ} \mathbf{C}\right)$ & USST $\left({ }^{\circ} \mathbf{C}\right)$ & EC (Unit) & SCC (Lakhs/ml) \\
\hline Non-mastitis & $37.23 \pm 0.08$ & $37.22 \pm 0.04^{\mathrm{a}}$ & $12.0 \pm 6.95^{\mathrm{a}}$ & $2.04 \pm 0.85^{\mathrm{a}}$ \\
SCM & $37.22 \pm 0.04$ & $38.08 \pm 0.17^{\mathrm{b}}$ & $58.18 \pm 25.65^{\mathrm{b}}$ & $8.16 \pm 0.99^{\mathrm{b}}$ \\
Clinical mastitis & $37.22 \pm 0.08$ & $38.25 \pm 0.33^{\mathrm{c}}$ & $146.25 \pm 36.22^{\mathrm{c}}$ & $21.05 \pm 1.34^{\mathrm{c}}$ \\
p value & 0.712 & 0.000 & 0.000 & 0.000 \\
\hline
\end{tabular}

Values with different superscripts with in the column differ significantly at $p<0.001, B T=$ Body temperature, USST=Udder skin surface temperature, EC=Electrical conductivity, SCC =Somatic cell count, HF=Holstein Friesian, SD=Standard deviation
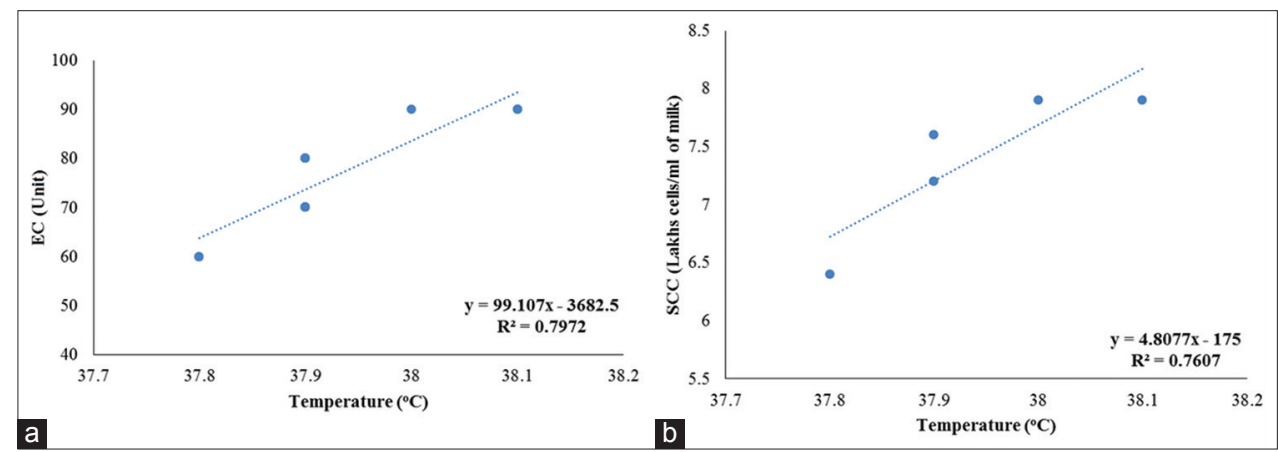

Figure-3: $(a$ and $b)$ Linear regression relating udder skin surface temperature with electrical conductivity (EC) and somatic cell count (SCC) of subclinical mastitis-affected crossbred cows.

with SCC of $<400,000$ cells per ml, which is similar to the present results of our study where a moderate correlation of USST with SCC was observed. The mean \pm SD SCC values (lakhs cells per ml of milk) were $2.05 \pm 0.85$ (0.6-3.6), 8.16 \pm 0.99 (6.4-9.6) and $21.05 \pm 1.34$ (20.1-22.0) and the mean USST values $\left({ }^{\circ} \mathrm{C}\right)$ were $37.22 \pm 0.04,38.08 \pm 0.18$ and $38.25 \pm 0.33$ for the quarters with CMT score negative $(\mathrm{n}=57)$, trace $(\mathrm{n}=11)$ and $+1(\mathrm{n}=8)$, respectively (Table- $1 \& 2)$. The mastitis indicators studied in this study were interrelated. The USST was positively correlated with EC and SCC (0.95 and 0.93). This relationship was, expectedly linear as the EC and SCC values increased, USST linearly increased (0.79 and 0.76) (Figure-3). In this study, out of 19 animals only one animal which was detected for SCM by IRT method, showed clinical mastitis in due course of time.

The ROC curve analysis revealed a higher sensitivity and specificity at $95 \%$ confidence interval with a range of $71.51-100 \%$ and $83.16-100 \%$, respectively, for USST with SCC and CMT in early prediction of SCM quarter $(>4$ lakhs $/ \mathrm{ml})$ with a cut-off value of $>37.61^{\circ} \mathrm{C}$ in crossbred cows. The USST of $>37.61^{\circ} \mathrm{C}$ was set as cut-off value in early prediction of SCM (Figure-4). This finding agrees with Polat et al. [8] they found the USST (mean \pm standard error) of $33.45 \pm 0.09^{\circ} \mathrm{C}$ and $35.80 \pm 0.08^{\circ} \mathrm{C}$ for healthy $(<4$ lakhs cells $/ \mathrm{ml})$ and SCM $(>4000$ lakhs $/ \mathrm{ml})$ affected quarters. The sensitivity and specificity were 95.6 and 93.6 for IRT and 88.9 and 98.9 for CMT in relation to SCM.

\section{Conclusion}

This study demonstrates for the first time that in HF crossbred cows the body and USST differentials with a cut-off value of $>37.61^{\circ} \mathrm{C}$ could detect the early

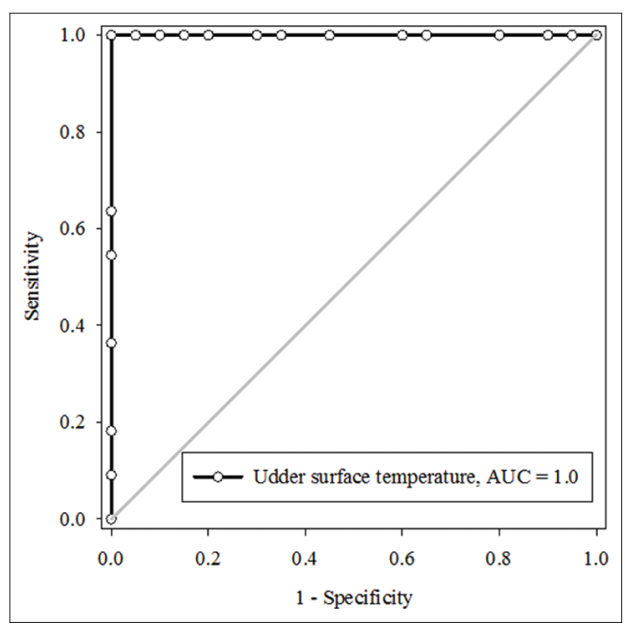

Figure-4: Area of udder skin surface temperature under the receiver operating characteristic curve.

occurrence of SCM in a dairy herd when monitored continuously using IRT. The results of the present study in lactating HF crossbred cows suggest that IRT was sensitive enough to detect thermal changes and rise in USST in relation to naturally occurring SCM and clinical mastitis. The diagnostic reliability is also well correlated with other mastitis indicators, viz., SCC, CMT and EC, indicating IRT of udder could be employed as one of the most potential, non-invasive, quick, cow-side diagnostic tool to monitor udder health and early detection of SCM in dairy animals.

\section{Authors' Contributions}

MS, SJ, AM, HAP, MS, KPR, DND, and MAK have formulated the research plan, MS, SJ and AM conducted experimental procedures and prepared the drafted manuscript. GJ and TKP assisted in collecting 
and compiling the resource material and in manuscript preparation. All authors read and approved the final manuscript.

\section{Acknowledgments}

The authors thank the Head, SRS, Director, Indian Council of Agricultural Research - NDRI for providing needful facilities and post-graduate research fellowship support from National Dairy Research Institute. The authors are grateful to the staff of veterinary dispensary and LRC for their assistance.

\section{Competing Interests} interests

The authors declare that they have no competing

\section{References}

1. Food and Agricultural Organization (FAO). (2014) Food Outlook Biannual Report on Global Food Market. Food and Agricultural Organization, United Nations.

2. Sharma, N., Rho, G.J., Hong, Y.H., Kang, T.Y., Lee, H.K., Hur, T.Y. and Jeong, D.K. (2012) Bovine mastitis: An Asian perspective. Asian J. Anim. Vet. Adv., 7: 454-476.

3. Halasa, T., Huijps, K., Osteras, O. and Hogeveen, H. (2007) Economic effects of bovine mastitis and mastitis management: A review. Vet. Q., 29: 18-31.

4. Kurjogi, M.M. and Kaliwal, B.B. (2014) Epidemiology of bovine mastitis in cows of Dharwad District. Int. Sch. Res. Notices, 2014: 1-9.

5. Jingar, S.C., Mehla, R.K., Singh, M., Kumar, A., Kantwa, S.C. and Singh, N. (2014) Comparative study on the incidence of mastitis during different parities in cows and buffaloes. Indian J. Anim. Res., 48(2): 194-197.

6. Antanaitis, R., Zilaitis, V., Juozaitiene, V., Palubinskas, G., Kucinskas, A., Sederevicius, A. and Beliavska-Aleksiejune, D. (2015) Efficient diagnostics and treatment of bovine mastitis according to herd management parameters. Vet. Med. Zootec., 69(91): 3-10.

7. Dua, K. (2001) Incidence, etiology and estimated economic losses due to mastitis in Punjab and in India-an update. Indian Dairyman, 53: 41-48.

8. Polat, B., Colak, A., Cengiz, M., Yanmaz, L.E., Oral, H., Bastan, A., Kaya, S. and Hayirli, A. (2010) Sensitivity and specificity of infrared thermography in detection of subclinical mastitis in dairy cows. J. Dairy Sci., 93: 3525-3532.

9. Hovinen, M., Siivonen, J., Taponen, S., Hanninen, L., Pastell, M., Aisla, A.M. and Pyorala, S. (2008) Detection of clinical mastitis with the help of a thermal camera. J. Dairy Sci., 91: 4592-4598

10. Colak, A., Polat, B., Okumus, Z., Kaya, M., Yanmaz, L.E. and Hayirli, A. (2008) Short communication: Early detection of mastitis using infrared thermography in dairy cows. J. Dairy Sci., 91(11): 4244-4248.

11. Metzner, M., Sauter-Louis, C., Seemueller, A., Petzl, W. and Klee, W. (2014) Infrared thermography of the udder surface of dairy cattle: Characteristics, methods, and correlation with rectal temperature. Vet. J., 199: 57-62.

12. Saravanan, R., Das, D.N., De, S. and Panneerselvam, S. (2015) Effect of season and parity on somatic cell count across zebu and crossbred cattle population. Indian J. Anim. Res., 49(3): 383-387.

13. Bar, D., Tauer, L.W., Bennett, G., Gonzalez, R.N., Hertl, J.A., Schukken, Y.H., Schulte, H.F., Welcome, F.L. and Grohn, Y.T. (2008) The cost of generic clinical mastitis in dairy cows as estimated by using dynamic programming. J. Dairy Sci., 91: 2205-2214.

14. Costa, A.C., Caja, G., Salama, A.A.K., Rovai, M., Flores, C. and Aguilo, J. (2014) Thermographic variation of the udder of dairy ewes in early lactation and following an Escherichia coli endotoxin intramammary challenge in late lactation. J. Dairy Sci., 97: 1377-1387.

15. Kunc, P., Knizkova, I., Prikryl, M. and Maloun, J. (2007) Infrared thermography as a tool to study the milking process. Agric. Trop. Subtrop., 40(1): 29-32.

16. Hurnik, J.F., De Boer, S. and Webster, A.B. (1984) Detection of health disorders in dairy cattle utilizing a thermal infrared scanning technique. Can. J. Anim. Sci., 64: 1071-1073.

17. Scott, S.L., Schaefer, A.L., Tong, A.K.W. and Lacasse, P. (2000) Use of infrared thermography for early detection of mastitis in in dairy cows. Can. J. Anim. Sci., 80: 764.

18. Jones, B.F. and Plassmann, P. (2002) Digital infrared thermal imaging of human skin. IEEE Eng. Med. Biol., 21: 41-48.

19. Willits, S. (2005) Infrared Thermography for Screening and Early Detection of Mastitis in Working Dairy Herds. InfraMation, 2005 Proceedings

20. Barth, K. (2000) Basic investigations to evaluate a highly sensitive infrared-thermograph technique to detect udder inflammation in cows. Milk Sci. Int., 55: 607-609.

21. Viguier, C., Arora, S., Gilmartin, N., Welbeck, K. and O'kennedy, R. (2009) Mastitis detection: Current trends and future perspectives. Trends Biotechnol., 27(8): 486-493.

22. Sears, P.M. and McCarthy, K.K. (2003) Diagnosis of mastitis fortherapy decisions. Vet. Clin. North Am. Food Anim. Pract., 19: 93-108

23. New York State Cattle Health Assurance Program Veterinary Resource. Diagnosis of Mastitis and Diagnostic Method for Investigating Udder Health Problems. Available from: https://www.ahdc.vet.cornell.edu. Last accessed on 30-06-2016.

24. McDougall, S. (1998) Efficacy of two antibiotic treatments in curing clinical and subclinical mastitis in lactating dairy cows. N. Z. Vet. J., 46: 226-232.

25. McDermott, M.P., Erb, H.N. and Natzke, R.P. (1982) Predictability by somatic cell counts related to prevalence of intramammary infection within herds. J. Dairy Sci., 65: 1535-1539.

26. Sargeant, J.M., Leslie, K.E., Shirley, J.E., Pulkrabek, B.J. and Lim, G.H. (2001) Sensitivity and specificity of somatic cell count and California mastitis test for identifying intramammary infection in early lactation. J. Dairy Sci., 84: 2018-2024

27. Hillerton, J.E. and Walton, A.W. (1991) Identification of subclinical mastitis with hand held electrical conductivity meter. Vet. Res., 128: 513-515. 